https://doi.org/10.5817/NR2019-1-15

\section{Nový transliterační nástroj Ústavu slavistiky FF MU}

Na Ústavu slavistiky vznikl a na jaře byl spuštěn nový transliterační nástroj pro přepis (transliteraci) cyrilicí psaných textů do latinky: <https://translit.slavistika. phil.muni.cz/>.

Domníváme se, že vznik takového nástroje byl potřebný, nebơ dosavadní zájemci o transliteraci museli využívat různých jiných nástrojů rozesetých různě po internetu, které se od sebe navzájem lišily mj. použitou normou transliterace. Nezřídka také nástroje, které se zdály být zavedené, přestaly ze dne na den fungovat. A protože transliterací textů různého typu - v poslední době především transliterace bibliografií $\mathrm{u}$ prríspěvků $\mathrm{v}$ časopisech a sbornících, jež jsou zařazeny do některé $\mathrm{z}$ vědeckých databází, př́padně o vstup do nich usilují -, přibývá, je nepraktické transliteraci provádět ručně, kdy se navíc zvyšuje riziko, že uděláme chybu.

$\mathrm{Z}$ tohoto důvodu se techničtí editoři časopisů a sborníků Ústavu slavistiky FF MU rozhodli pro vývoj vlastního transliteračního nástroje, který by byl pod jejich správou a u něhož by tudíž zaprvé nehrozilo, že přestane fungovat, a zadruhé by odpovídal potřebám a transliterační normě, která je zde využívána. Tou je Doporučení pro prépis nelatinkových písem do latinky [Doporučení... 2006], které vypracovala a které využivá Národní Knihovna ČR. Aplikace zmíněné normy $\mathrm{v}$ publikacích Ústavu slavistiky FF MU je tak podpořeno vahou této významné instituce $\mathrm{v}$ oblasti knihovnictví a katalogizace. Norma však v současné době prochází přepracováním a aktualizací [Transliterace... 2019], což je již zohledněno $\mathrm{v}$ transliteračním nástroji; ten odráží poslední stav z roku 2018. Informace a dokumenty uvedené na webu NK ČR nahrazují tištěnou příručku.

Webové prostředí transliteračního nástroje je dostupné ve třech jazykových verzích (vedle češtiny také angličtina a ruština) a transliterovat je možné $\mathrm{z}$ jazyků, které př́slušná norma zmiňuje: $\mathrm{z}$ ruštiny, běloruštiny, ukrajinštiny, bulharštiny, makedonštiny a srbštiny. Bosenština a černohorština jsou zařazeny pod srbštinu a rusínština pod ukrajinštinu. Do horního okénka se vkládá text, jejž chceme transliterovat, $\mathrm{v}$ dolním okénku se text současně automaticky přepisuje dle zvoleného jazyka. V dolním okénku nelze text editovat, lze jej pouze zkopírovat (kliknutím na tlačítko „kopírovat“ nebo označením textu a klávesovou zkratkou CTRL+C). Velkou výhodou transliterace je, že se zachovává formátování textu: pokud tedy vložíme text např. z MS Word, kde máme kurzivou vyznačené názvy knih, při přepisu se toto formátování neztratí. $\mathrm{V}$ zápatí stránky nalezneme odkaz na př́slušnou normu NK ČR.

Změny v současné přepracované normě oproti té z roku 2006 jsou:

- Srbské „„“" se přepisuje jako „j“, nikoliv jako ," “" jedan $\times$ jedan.

- Rusínské „Ы“ se přepisuje jako „y்“, nikoliv jako „y“: jazỳk × jazyk. 


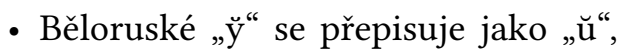
nikoliv jako „ü“: sloŭnik × sloǔnik.

- Měkký a tvrdý znak se transliterují podobným znakem (', resp. "), ovšem s jiným kódováním Unicode.

- Apostrof v běloruštině a ukrajinštině byl dříve přepisován speciálním znakem ', nyní „obyčejným“ apostrofem ' ${ }^{1}$

Protože je transliterační nástroj ve správě Ústavu slavistiky FF MU, je možné ho $\mathrm{v}$ budoucnu vylepšovat a rozšiřovat, tak jak si to vyžádá praxe. V úvahách jsou např́iklad doplnění, jako je zpětná transliterace do cyrilice (což však naráží na svá úskalí), transliterace podle jiné normy (např́klad některé z anglických/ /amerických), přidání transliterace dalších jazyků využívajících cyrilici nebo např. přepis staré ruštiny nebo dokonce staroslověnštiny apod. Pro poslední dvě zmíněné možnosti by měly být v budoucnu vypracovány odpovídající transliterační tabulky.

Prosíme uživatele, aby se $\mathrm{v}$ př́padě objevení chyby v transliteraci obrátili na redakci časopisu Новая русистика.

Zbyněk Michálek

\section{Bibliografie:}

Doporučení pro přepis nelatinkových písem do latinky (2006). Praha.

1 Veškeré kódování Unicode je uvedeno v tabulkách. Jelikož jde často o znaky, které je problematické nebo i nemožné napsat pomocí běžné klávesnice (různá diakritika apod.), doporučujeme využívat webovou „Digitální Rosettskou desku“ [File... 2019].
FileFormat.Info. The Digital Rosetta Stone (2019). <http://www.fileformat.info/ index.htm>. [online]. [cit. 8. 5. 2019]. Transliterace nelatinkových písem (2019). $<$ https://www.nkp.cz/o-knihovne/ odborne-cinnosti/zpracovani-fondu/ transliterace-nelatinkovych-pisem/ transliterace-nelatinkovych-pisem>. [online]. [cit. 8. 5. 2019].

https://doi.org/10.5817/NR2019-1-16

\section{Aktuální otázky současné jazykovědné rusistiky VI - zpráva z kolokvia}

Dne 10. května 2019 proběhlo v zasedací místnosti děkanátu FF MU kolokvium Aktuální otázky současné jazykovědné rusistiky VI, jež neslo podtitul Pragmatika - syntax - sémantika. Kolokvium bylo uspořádáno u příležitosti nedožitých 90. narozenin předního českého lingvisty, především rusisty a klasického filologa, ale také bohemisty a slavisty obecně, Prof. PhDr. Stanislava ŽažI, CSc. (14. 4. 1929 - 5. 8. 2018), jejž netřeba odborné veřejnosti podrobněji představovat. Setkání českých, slovenských a ruských rusistů zorganizoval Ústav slavistiky FF MU a Česká asociace slavistů.

Po registraci účastníků přivítal přítomné organizátor setkání doc. PhDr. Jiří Gazda, CSc., děkan FF MU prof. PhDr. Milan Pol, CSc., a vedoucí Ústavu slavistiky FF MU a předseda České asociace 